\title{
TUTUPAN LAMUN Thalassia hemprichii DI PERAIRAN DUSUN KARANG UTARA, PULAU LEMUKUTAN, KABUPATEN BENGKAYANG, KALIMANTAN BARAT
}

\author{
Dwi Gusmalawati ${ }^{a, b}$ * dan Aulia Seto Sandhi Sanova \\ ${ }^{a}$ Program Doktor Biologi FMIPA Universitas Brawijaya Malang JawaTimur, Indonesia

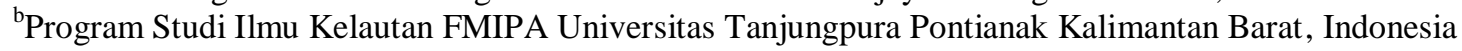 \\ *Corresponding author: dwi_gusmalawati@yahoo.com
}

\begin{abstract}
Abstrak
Ekosistem padang lamun merupakan habitat bagi ikan dan biota perairan lainnya. Berbagai jenis penyu juga menjadikan daerah padang lamun sebagai daerah mencari makan, khususnya di perairan Pulau Lemukutan, Kalimantan Barat. Tutupan lamun, khususnya jenis Thalassia hempricii di perairan Dusun Karang Utara, Pulau Lemukutan belum diketahui. Data mengenai tutupan lamun ini akan dijadikan sebagai acuan dalam pengelolaan wilayah perairan tersebut. Penelitian dilakukan pada 4 stasiun di perairan Dusun Karang Utara, Pulau Lemukutan, Kalimantan Barat. Stasiun pengamatan memiliki panjang $50 \mathrm{~m}$ tegak lurus terhadap garis pantai. Setiap stasiun dibagi menjadi 5 plot transek. Pemilihan plot transek dilakukan dengan metode purposive random sampling. Transek kuadrat yang digunakan adalah berukuran 1 x $1 \mathrm{~m}$ dengan setiap pixelnya berukuran $20 \mathrm{~cm}$ x $20 \mathrm{~cm}$. Hasil nilai rata-rata persentase tutupan lamun pada stasiun 1, 2, 3 dan 4 adalah 2,68\%; 2,34\%, 11,4\% dan 9,8\% secara berurutan. Kondisi persentase tutupan lamun Thalassia hempricii di Perairan dusun Karang Utara, Pulau Lemukutan ini termasuk dalam kategori sedikit. Parameter fisika-kimia air laut di Perairan Dusun Karang Utara, Pulau Lemukutan adalah arus $0,2 \mathrm{~m} / \mathrm{s}$, suhu $30,5^{\circ} \mathrm{C}$, salinitas $32 \%$, kedalaman $0,5-1 \mathrm{~m}$, dan $\mathrm{pH} 8,5$.
\end{abstract}

Kata kunci: tutupan, lamun, Lemukutan, Kalimantan Barat

\begin{abstract}
Seagrass ecosystem is a habitat for fish and other aquatic biota. Various types of sea turtles also make seagrass ecosystems as a foraging area, especially in the waters of Lemukutan Island, West Kalimantan. Seagrass cover, especially Thalassia hempricii in the waters of North Karang Hamlet, Pulau Lemukutan is unknown. Data regarding seagrass cover will be used as a reference in the management of these waters. The study was conducted at 4 stations in the waters of the North Karang Hamlet, Pulau Lemukutan, West Borneo. The observation station has a length of $50 \mathrm{~m}$ perpendicular to the coastline. Each station is divided into 5 transect plots. The selection of the transect plot was done by purposive random sampling method. The squared transect used is $1 \times 1 \mathrm{~m}$ with each pixel measuring $20 \mathrm{~cm} \times 20 \mathrm{~cm}$. The results of the average percentage of seagrass cover percentage at stations 1, 2, 3 and 4 were $2.68 \%, 2.34 \%, 11.4 \%$ and $9.8 \%$ respectively. The condition of the percentage of cover of Thalassia hempricii seagrass in the waters of the North Karang Hamlet, Lemukutan Island is included in the few categories. Physico-chemical parameters of seawater in the waters of North Karang Hamlet, Lemukutan Island are currents of $0.2 \mathrm{~m} / \mathrm{s}$, temperature of $30.5^{\circ} \mathrm{C}$, salinity of $32^{\circ} \%$, depth of $0.5-1 \mathrm{~m}$, and $\mathrm{pH}$ of 8.5 .
\end{abstract}

Keywords: Cover, Thalassia hempricii seagrass, Lemukutan, West Borneo

\section{PENDAHULUAN}

Ekosistem yang sangat penting dan saling mempengaruhi di wilayah pesisir dan lautan yaitu ekosistem mangrove, ekosistem padang lamun, dan ekosistem terumbu karang. Ketiga ekosistem tersebut, memiliki fungsi yang sangat kompleks dan berfungsi sebagai penyangga (buffer) bagi kehidupan di darat maupun di laut. Interaksi antara ekosistem tersebut, sangat penting dalam menjaga kawasan pesisir dan lautan [1].

Ekosistem lamun merupakan ekosistem pada wilayah perairan dangkal yang terdapat di antara ekosistem mangrove dan ekosistem terumbu karang. Ekosistem lamun di Indonesia memiliki luas sekitar $30.000 \mathrm{~km}^{2}$ dan berperan penting di ekosistem laut 
dangkal, karena merupakan habitat bagi ikan dan biota perairan lainnya [2],[3]. Berbagai jenis penyu menjadikan ekosistem lamun sebagai daerah mencari makan (feeding ground). Selain itu, untuk jenis ikan menjadikan ekosistem lamun sebagai tempat pengasuhan larva (nursery ground), tempat memijah (spawning ground), sebagai stabilitas dan penahan sedimen, mengurangi dan memperlambat pergerakan gelombang, sebagai tempat terjadinya siklus nutrient [4], [5], dan fungsinya sebagai penyerap karbon di lautan [6].

Terdapat 60 jenis lamun di seluruh dunia [7], 20 jenis di ditemukan di Asia Tenggara 12 diantaranya dapat dijumpai di perairan Indonesia [8]. Penyebaran padang lamun di Indonesia cukup luas, mencakup hampir seluruh perairan nusantara yakni Jawa, Sumatera, Bali, Kalimantan, Sulawesi, Maluku, Nusa Tenggara, dan Irian Jaya. Lamun dapat tumbuh pada daerah perairan dangkal yang agak berpasir atau berlumpur dan masih dapat dijumpai sampai kedalaman 40 meter dengan penetrasi cahaya yang masih baik [9].

Salah satu pulau di Kalimantan Barat yang dapat dijumpai lamun adalah Pulau Lemukutan. Pulau Lemukutan sejak tahun 2004 telah menjadi sebuah Kawasan Konservasi Laut Daerah (KKLD) berdasarkan Surat Keputusan Bupati Bengkayang No. 220. Tahun 2004 tentang Penetapan lokasi pulau Lemukutan dan pulau-pulau di sekitarnya sebagai Kawasan Konservasi Laut Daerah (KKLD) Kabupaten Bengkayang, yang meliputi (i) zona preservasi/zona inti (daratan Pulau), (ii) zona konservasi (Pantai berhutan bakau, habitat penyu, perairan pantai untuk terumbu karang (Master Plan KKLD-DKP Prov. Kalbar, 2005).

Kerusakan lamun dapat disebabkan oleh meningkatnya aktifitas manusia. Pada saat ini Pulau Lemukutan menjadi salah satu tujuan wisata di Kalimantan Barat. Dengan demikian akan berpengaruh terhadap ekosistem di pulau tersebut, terutama ekosistem lamun. Permasalahan yang terjadi adalah ekosistem lamun tidak mendapat perhatian yang lebih, khususnya jenis Thalassia hemprichii. Tidak seperti ekosistem terumbu karang, rumput laut dan mangrove, ekosistem lamun sampai saat ini masih kurang mendapat perhatian [10]. Hal ini diakibatkan oleh masyarakat yang tidak mengerti fungsi dari ekosistem lamun. Penelitian ini bertujuan untuk mengetahui tutupan lamun Thalassia hemprichii di Perairan Dusun Karang Utara, Pulau Lemukutan, Kabupaten Bengkayang, Kalimantan Barat. Manfaat penelitian ini diharapkan dapat memberikan informasi kepada masyarakat mengenai tutupan dan keadaan lamun Thalassia hemprichii sebagai acuan dalam pengelolaan perairan Dusun Karang Utara, Pulau Lemukutan, Kabupaten Bengkayang, Kalimantan Barat.

\section{MATERI DAN METODE}

Pengambilan data penelitian dilakukan di Perairan Dusun Karang Utara, Pulau Lemukutan, Kabupaten Bengkayang, Kalimantan Barat pada bulan September 2016.

\section{Metode Pengambilan dan Pengamatan Data Lamun}

Metode yang digunakan dalam pengambilan data yaitu dengan menggunakan transek kuadrat. Transek kuadrat yang digunakan dalam penelitian ini berukuran $1 \mathrm{~m}$ $\mathrm{x} 1 \mathrm{~m}$ dengan setiap pixelnya berukuran 20 $\mathrm{cm} \times 20 \mathrm{~cm}$, sehingga dalam satu transek kuadrat terdapat 25 pixel. Pemilihan plot transek dilakukan dengan metode purposive random sampling [11]-[13].

Pengambilan dan pengamatan lamun dilakukan pada siang hari yaitu pada saat laut dalam kondisi surut. Pada penelitian ini terdapat 4 stasiun yang masing-masing stasiun terdapat 5 plot transek. Stasiun pengamatan memiliki panjang $50 \mathrm{~m}$ tegak lurus terhadap garis pantai. Untuk pengamatan struktur komunitas lamun dimulai dari arah laut menuju darat. Variabel yang diamati adalah spesies lamun mencakup kerapatan jenis dan parameter fisika kimia [11],[14].

\section{Analisis Data \\ Penutupan Jenis}

Untuk mengetahui luas area penutupan jenis lamun tertentu dibandingkan dengan luas 
total area penutupan untuk seluruh jenis lamun, digunakan metode Saito dan Adobe [11].

$$
\mathrm{C}=\frac{\sum\left(\mathrm{M}_{\mathrm{i}} \mathrm{xf}_{\mathrm{i}}\right)}{\sum \mathrm{f}}
$$

Dengan :

$\mathrm{C}=$ presentase penutupan jenis lamun $i$,

$\mathrm{Mi}=$ presentase titik tengah dari kelas kehadiran jenis lamuni,

$f i \quad$ = banyaknya sub petak dimana kelas kehadiran jenis lamun i sama.

Penutupan relatif adalah perbandingan antara penutupan individu jenis ke-i dengan jumlah total penutupan seluruh jenis. Penutupan relatif jenis dihitung dengan menggunakan rumus [15]:

$$
\mathrm{RC}_{\mathrm{i}}=\frac{\mathrm{C}_{\mathrm{i}}}{\Sigma \mathrm{C}} \times 100 \%
$$

Dengan:

$\mathrm{Ci}=$ Luas area penutupan jenis

$\Sigma \mathrm{C}=$ Luas total area penutupan untuk seluruh jenis

$\mathrm{RC} \mathrm{i}=$ Penutupan relatif jenis

\section{Pengukuran Parameter Fisika-Kimia Air laut}

Pengukuran parameter fisika-kimia air laut meliputi: suhu, salinitas, kedalaman, kecepatan arus dan $\mathrm{pH}$ [12], [17].
Suhu

Suhu perairan permukaan diukur dengan menggunakan termometer air raksa dari atas perahu. Termometer dimasukkan ke dalam air selama kurang lebih 1 menit, pembacaan nilai suhu dilakukan sesaat setelah termometer diangkat ke permukaan agar menghindari perubahan nilai akibat pengaruh suhu permukaan udara.

\section{Salinitas}

Salinitas diukur dengan menggunakan refraktometer. Sebelum diukur terlebih dahulu refraktometer dibilas dengan akuades yang bertujuan untuk mensterilkan kaca objek dan sebagai kalibrasi. Setelah dikalibrasi dilap dengan tisu sampai bersih, lalu mulai dilakukan pengukuran dengan meletakkan air contoh pada kaca objek.

\section{Kedalaman}

Kedalaman perairan diukur dengan menggunakan tiang berskala. Alat ini ditenggelamkan tegak lurus hingga menyentuh dasar perairan pada lokasi penelitian.

\section{pH dan Kecepatan Arus}

$\mathrm{pH}$ air laut diukur dengan menggunakan $\mathrm{pH}$ meter dan kecepatan arus diukur dengan menggunakan current meter.

Tabel 1. Skala kondisi lamun berdasarkan kerapatan [16].

\begin{tabular}{ccl}
\hline Skala & Kerapatan $\left(\right.$ ind $\left./ \mathrm{m}^{2}\right)$ & \multicolumn{1}{c}{ Kondisi } \\
\hline 5 & $>175$ & Sangat rapat \\
4 & $125-175$ & Rapat \\
3 & $75-125$ & Agak rapat \\
2 & $25-75$ & Jarang \\
1 & $<25$ & Sangat jarang \\
\hline
\end{tabular}

Tabel 2. Skala kondisi lamun berdasarkan persentase tutupan [16].

\begin{tabular}{ccl}
\hline Skala & Persentase Tutupan & \multicolumn{1}{c}{ Kondisi } \\
\hline 5 & $>75 \%$ & Sangat bagus \\
4 & $50-75 \%$ & Bagus \\
3 & $25-50 \%$ & Agak bagus \\
2 & $5-25 \%$ & Sedikit \\
1 & $<5 \%$ & Sangat sedikit \\
\hline
\end{tabular}


Tabel 3. Status lamun berdasarkan persentase tutupan [11]

\begin{tabular}{|l|l|c|}
\hline \multicolumn{2}{|c|}{ KONDISI } & PENUTUPAN (\%) \\
\hline BAIK & KAYA/SEHAT & $\geq 60$ \\
\hline \multirow{2}{*}{ RUSAK } & KURANG KAYA/KURANG SEHAT & $30-59,9$ \\
\cline { 2 - 3 } & MISKIN & $\leq 29,9$ \\
\hline
\end{tabular}

\section{HASIL DAN PEMBAHASAN}

\section{Persentase dan kategori tutupan lamun}

Grafik persentase tutupan lamun Thalassia hempricii di Perairan Dusun Karang Utara, Pulau Lemukutan Kabupaten Bengkayang Kalimantan Barat menunjukkan rata-rata tutupan di 4 stasiun (Gambar 1). Persentase tutupan lamun Thalassia hemprichii sepanjang line transek $50 \mathrm{~m}$ di Stasiun 1 adalah tertinggi $15,62 \%$ di kuadran ke 2, sedangkan yang terendah $1,5 \%$ di kuadran ke 1. Nilai rata-rata tutupan lamun 2,68\% menunjukkan bahwa tutupan lamun Thalassia hemprichii di stasiun 1 masuk dalam kategori sangat sedikit. Pada stasiun 2 presentase tutupan lamun hanya ditemukan $14.6 \%$ di kuadran ke 1 sepanjang transek $50 \mathrm{~m}$ dengan nilai rata-rata tutupan lamun 2,34\% menunjukkan bahwa tutupan lamun Thalassia hemprichii di stasiun 2 masuk dalam kategori sangat sedikit. Pada stasiun 3, presentase tutupan lamun tertinggi di kuadran ke 3 dengan nilai $45 \%$ dan terendah di kuadran ke 1 dengan nilai $7,8 \%$. Nilai rata-rata tutupan lamun $11,4 \%$ menunjukkan bahwa tutupan lamun Thalassia hemprichii di stasiun 3 masuk dalam kategori sedikit. Pada stasiun 4, persentase tutupan tertinggi pada kuadran ke 1 dengan nilai $58 \%$ sedangkan di kuadran lainnya tidak ditemukan tutupan lamun. Nilai persentase rata-rata tutupan lamun Thalassia hemprichii di stasiun 4 adalah 9,8\% termasuk dalam kategori sedikit (Gambar 2). Status lamun di Perairan Dusun Karang Utara, Pulau lemukutan kabupaten Bangkayang Kalimantan Barat berdasarkan persentase tutupan lamun Kemen LH (2004) yaitu dengan kondisi rusak, miskin karena persentase tutupannya $\leq 29,9$. Kerusakan ini disebabkan karena pada perairan ini sudah dijadikan tempat wisata. Aktivitas snorekling wisatawan yang kurang memperhatikan keberadaan lamun. Aktivitas motor air yang merupakan sarana transprotasi di Pulau tersebut diduga juga mempengaruhi pertumbuhan lamun, serta aktivitas masyarakat disekitas tepi pantai yang membuang sampah sembarangan.

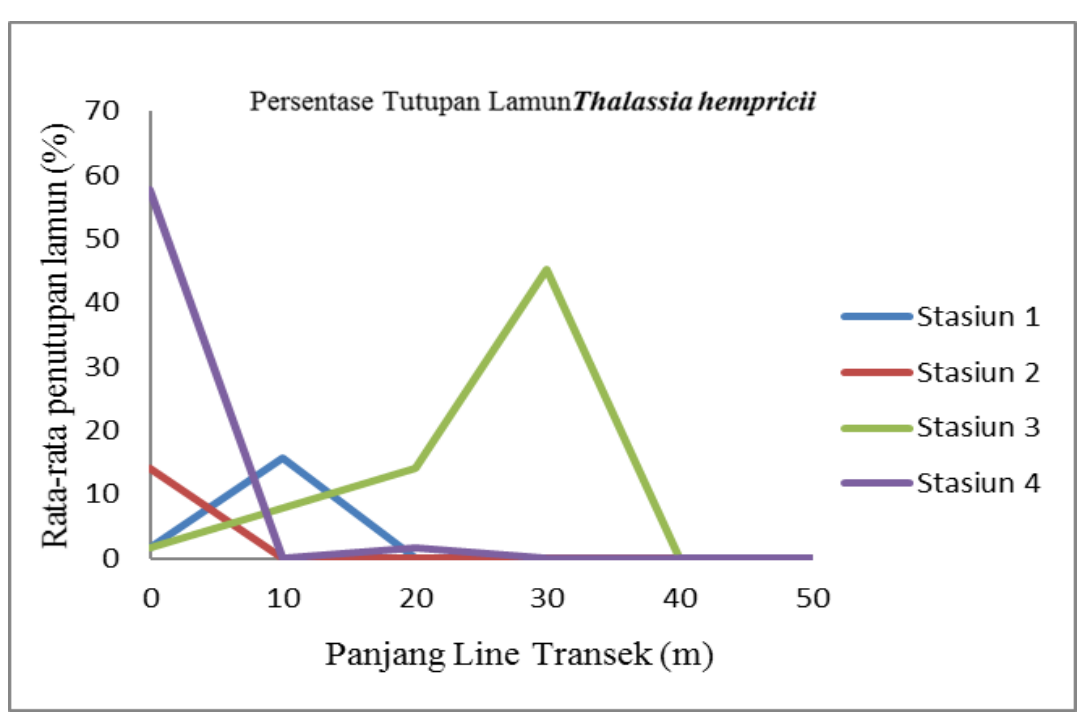

Gambar 1. Grafik persentase tutupan lamun Thalassia hemprichii di Perairan Dusun Karang Utara, Pulau Lemukutan 

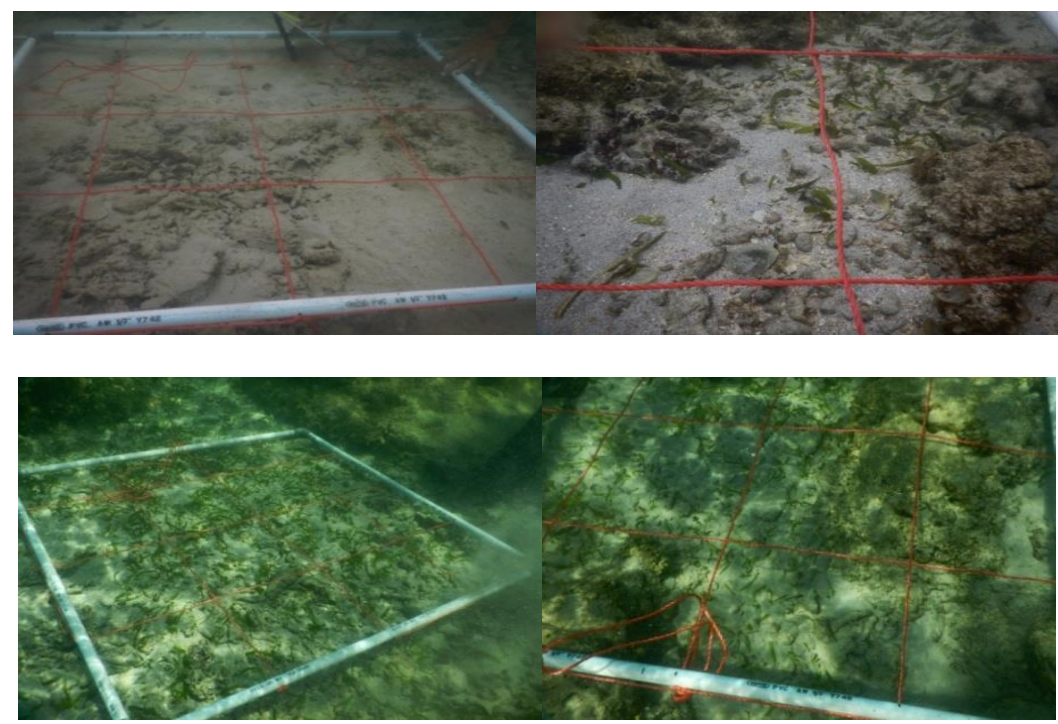

Gambar 2. Tutupan lamun Thalassia hemprichii di Perairan Dusun Karang Utara, Pulau Lemukutan, Kabupaten bengkayang Kalimantan Barat

Parameter fisika-kimia air laut yang diukur di Perairan dusun Karang Utara, Pulau Lemukutan adalah Arus $0.2 \mathrm{~m} / \mathrm{s}$, Suhu 30.5 ${ }^{\circ} \mathrm{C}$, Salinitas $32 \%$, Kedalaman 0.5-1 m, dan $\mathrm{pH}$ 8.5. kecepatan arus di lokasi penelitian sekitar $0.2 \mathrm{~m} / \mathrm{s}$, arus ini masih dapat di toleransi oleh lamun, dimana Thalassia hempricii membentuk vegetasi tunggal pada daerah seaward dari hamparan karang di daerah intertidal yang mendapat tekanan dari gelombang dan arus dengan kecepatan mencapai $2 \mathrm{~m} / \mathrm{s}$. Lamun jenis ini dapat hidup dengan suhu air berkisar $25-35^{\circ} \mathrm{C}$ sedangkan suhu air laut di lokasi penelitian berkisar 30.5${ }^{\circ} \mathrm{C}$ di mana lamun dapat melakukan proses fisiologis dengan baik. Pengukuran salinitas di stasiun penelitian menunjukkan nilai $32 \%$ o.

Lamun dapat mentolerir salinitas $10-40 \%$ dengan nilai optimumnya adalah $35 \%$ o. Keberadaan Thalassia hempricii sangat dipengaruhi oleh penetrasi cahaya matahari untuk proses fotosintesis. Hal ini terkait dengan kedalaman perairan, dimana Thalassia hempricii di stasiun penelitian berada dikedalaman 0.5-1 meter [18]. Sedangkan [19] menyatakan bahwa distribusi lamun tergantung oleh beberapa faktor yaitu kecerahan (dengan kedalaman < $10 \mathrm{~m}$ ), temperatur $\left(28-30^{\circ} \mathrm{C}\right)$, salinitas $\left(10-40^{\circ} \%\right.$ oo), substrat (40\% endapan lumpur kasar dan halus) dan kecepatan arus (sekitar $0,5 \mathrm{~m} / \mathrm{dt}$ ).

\section{KESIMPULAN}

Kondisi persentase tutupan lamun Thalassia hemprichii di Perairan Dusun Karang Utara, Pulau Lemukutan Kalimantan Barat termasuk dalam kategori sedikit dan rusak/miskin.

\section{DAFTAR PUSTAKA}

[1] Dahuri, R. 2003. Keanekaragaman Hayati Laut Aset Pembangunan Berkelanjutan Indonesia. Penerbit Gramedia Pustaka Utama. Jakarta.

[2] Azkab, MH. 1999. Pedoman Inventarisasi Lamun. Balai Penelitian Biologi Laut. Puslitbang Oseanologi LIPI. Jakarta.

[3] Nontji. 2005. Laut Nusantara. Djambatan. Jakarta.

[4] Philips, CR. \& EG. Menez. 1988. Seagrass. SmithSonian Institutions Press, Washington D.C.

[5] Dahuri, R. 1996. Pengelolaan Sumberdaya Pesisir dan Lautan Secara Terpadu. PT. Pramadya Paramita. Jakarta. 
[6] Kawaroe, M. 2009. Perspektif Lamun Sebagai Blue Carbon Sink di Laut. Lokakarya Nasional I Pengelolaan Ekosistem Lamun. 18 November 2009. Jakarta, Indonesia.

[7] Kuo, J dan C. Den Hartog. 2006. Seagrass Morphology, Anatomy, and Ultrastructure. Di dalam: Anthonyw.D. Larkum, A.D., R.J. Orth, and C.M. Duarte editor. Seagrasses: Biology, Ecologyand Conservation. Published by Springer, The Netherlands.

[8] Kordi, KMGH. 2011, Ekositem Lamun (Seagrass), Rineka Cipta. Yogyakarta.

[9] Hemminga, MA. \& CM. Duarte. 2000. Seagrass Ecology. Cambridge: Cambridge University Press. Australia.

[10] Bengen, DG. 2000. Pedoman Teknis Pengenalan dan Pengelolaan Ekosistem Mangrove.Pusat Kajian Sumberdaya Pesisir dan Lautan. Institut Pertanian Bogor. Bogor.

[11] Kepmen LH. Nomor 200. 2004. Kriteria Baku Kerusakan Dan Pedoman Penentuan Status Padang Lamun.

[12] Fachrul, MF. 2007. Metode Sampling Bioekologi 198 hlm. 2007. Bumi Aksara. Jakarta.
[13] Ferianita, M. 2007. Metode Sampling Bioekologi, PT Bumi Aksara. Jakarta.

[14] Fauziyah, IM. 2004. Sturktur Komunitas Padang Lamun di Pantai Jibar Sanur, Bali. Jurusan Ilmu Dan Teknoligi Kelautan Fakultas Perikanan Dan Ilmu Kelautan. Skripsi. IPB. Bogor.

[15] Odum, EP. 1971. Fundamental Of Ecology. Third Edition. W.B. Saunders Company. Philadelphia. $574 \mathrm{p}$

[16] Braun-Blanquet, J., 1965, Plant Sociology: The Study of Plant Communities, (Trans. rev. and ed. By C.D. Fuller and H.S. Conard), Hafner, London.

[17] Nur, C. 2011. Inventarisasi Jenis Lamun dan Gastropoda Yang Berasosiasi di Perairan Pulau Karangpuang, Mamuju, Propinsi Sulawesi Barat. Program Studi Ilmu Kelautan, Fakultas Ilmu Kelautan dan Perikanan Uversitas Hasanuddin, Makasar.

[18] Badna. 2007. Laju Pertumbuhan Daun Lamun Pada Dua Substrat Berbeda di Teluk Banten. IPB. Bogor.

[19] Dahuri, R, R Jacub, P.G Sapta, dan M. J. Sitepu. 2001. Pengelolaan Sumberdaya Wilayah Pesisir dan Lautan Terpadu, PT. Pradnya Paramita, Jakarta. 